\title{
Doop en wedergeboorte
}

Schutte Venter, Randburg

Jan $J$ van der Walt, Potchefstroom

\section{ABSTRACT \\ Baptism and regeneration}

The relation between baptism and regeneration is especially prominent in John $3: 3,5$ and Titus $3: 5$ although elsewhere in the New Testament there are also important references to the subject. God is of paramount importance for both baptism and regeneration: in baptism God's command is obeyed by man in receiving God's sign, and in regeneration God Himself executes his deed of salvation in a person's life. The reign of Jesus Christ and the personal bond between Jesus and the believer are the ground for both baptism and regeneration. Here the work of the Holy Spirit is also of utmost importance. By being baptized and born again a person knows that he is part of the kingdom of God and that he may be assured of the eschatological inheritance promised by God to his children. A believer experiences the practical meaning of his baptism and regeneration in being certain of his salvation and by breaking with the bonds of sin. The actual renewal of a sinner's life is not brought about by his baptism, but by his being reborn. In the life of a believer the most important issues in this regard should be that he knows that he is a baptized and reborn person, rather than the question of when, or in which sequence, it happened.

"As iemand nie opnuut gebore word nie, kan hy die koninkryk van God nie sien nie." (Joh $3: 3$ 1983-vertaling.)

"As iemand nie uit water en Gees gebore word nie, kan hy nie in die koninkryk van God kom nie." (Joh $3: 5$ 1983-vertaling.)

So beskryf Jesus Christus aan die begin van sy werk hoe die evangelie elke gelowige se lewe raak. Daar moet iets met die enkeling gebeur. Voordat hy in die koninkryk van God kan kom, moet hy "uit water en Gees gebore word".

"Gaan dan heen, maak dissipels van al die nasies, en doop hulle in die Naam van die Vader en die Seun en die Heilige Gees." (Matt 28 : 19 1953-vertaling.)

So beskryf Jesus Christus aan die einde van sy werk op aarde hoe elke gelowige deur die doop in die koninkryk van God ingelyf word. Jesus is by die enkeling betrokke. Daarom is die enkeling deel van die kerk van Christus en moet by hom daarby voeg. 
Die doop en wedergeboorte raak inderdaad die bestaan van elkeen wat bely dat hy of sy ' $n$ lid van God se koninkryk is.

\section{GOD IS SENTRAAL}

Die persoonlike betrokkenheid van elke gelowige by sy eie doop, word in 1 Kor $6: 11$ beskryf met die woorde: "Julle bet julle laat afwas." Die aoristus-medium à $\pi \varepsilon \lambda$ ovoa $\sigma \varphi \tau$ dui aan dat die subjek "is participating in the result of the action" (Dana, 1955:157). Dit was dus vir die gelowiges belangrik dat hulle sondes afgewas word. Waarom? Omdat hulle "vrygespreek is in die Naam van die Here Jesus en deur die Gees van ons God" $(6: 11)$. Met die doop het hulle deel gekry aan die vergewing van hulle sondes deur die drie-enige God.

Die uitdrukking doop in die Naam beklemtoon die feit dat die dopeling deur die doop tot die gemeenskap en onder die seggenskap gebring word van Hom in wie se Naam hy gedoop is (Floor, 1983:28). Die voorsetsel kic in eiç tó óvoua (Matt $28: 19$ ) is 'n voorsetsel wat geinterpreteer kan word om beweging aan te dui: dit is diegene wat buite die Naam is, wat nou daarin gebring word. Hulle word van plek of toestand verander (Anon. 1876:41).

Hier is volgens Floor (1983:29), sprake van regeringsverandering. "Om egter die nuwe gesag, die heilsgesag van God, te erken, vra 'n radikale lewensvernuwing, 'n nuwe geboorte. Dit is die werk van die Heilige Gees." (Floor, 1983:30.) Hierdie lewensvernuwing word veral beskryf in Titus $3: 5$ : “. . . het Hy ons gered ( $(\varepsilon \sigma \omega \sigma \varepsilon v)$ deur $(\delta ı \alpha$ ) die bad van die

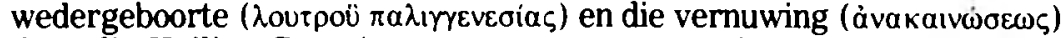

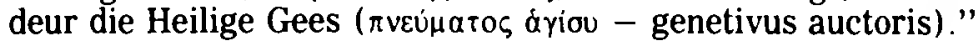

Om Titus $3: 5$ reg te verstaan, moet die verband met $3: 4$ in gedagte gebou word. Dit gaan om die inisiatief wat God neem in die lewe van 'n mens, op grond van God se goedertierenheid en liefde (vers 4) vir die mens en sy ontferming (vers 5) oor die mens. Die inisiatief van God word ook in vers 5 onderstreep: "nie op grond van die werke van geregtigheid wat ons gedoen het nie ...". Wanneer vers $5 b$ dan aandui dat Hy (God) ons gered het, wys "deur die bad van die wedergeboorte" daarop hoe God ons gered het. Die "bad van die wedergeboorte" is dus die wyse waarop God steeds die inisiatief behou in die redding van die mens.

Hierdie gegewens stem ooreen met die formulering van Jesus in Joh $3: 3$ waar Hy die woord ăv $\omega \theta \varepsilon v$ gebruik. Hierdie woord kan van plek (van bo af) of van tyd (opnuut) gebruik word. Die klem val in $3: 3$ eerder op die tyd, in die lig daarvan dat 3:4 oor die tyd handel (" 'n tweede keer") (vergelyk Lenski, 1943:233), daarom word a $v \omega \theta \varepsilon v$ met "weer" vertaal. Maar dit sluit nie uit nie dat Jesus in vers 5 juis die klem laat val op die plek (van bo af, naamlik van God af). "Daarom denken we aan een wedergeboorte uit den hemel, een niet aardsche, doch een geheel andere nieuwe geboorte ..." (Grosheide, 1950:208.)

In die wedergeboorte is dus sprake van die feit dat God die inisiatief neem om die regeringsverandering in die lewe van 'n mens te laat plaas- 
vind. Wat in die wedergeboorte geskied, vind plaas op grond van die ontferming van God (1 Pet $1: 3$ ).

Die doop geskied ook op grond van die ontferming van God vir die betrokke dopeling. In Titus $3: 5$ staan dat God ons gered het deur die bad van die wedergeboorte. $\Delta$ ia dui die wyse aan waarop God ons gered het.

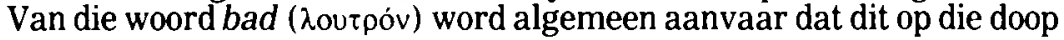
betrekking het (vergelyk onder andere Lock, 1936: 154; Ridderbos, 1967:286; Beare, 1970:81). So word God se liefde in die doop beseel.

In hierdie verband is die uitdrukking "uit God gebore" van belang (vergelyk Joh $1: 13,1$ Joh $2: 29 ; 3: 9 ; 4: 7 ; 5: 1,4,18$ ). Die perfektum (vergelyk $\gamma \varepsilon \gamma \dot{\varepsilon} v \eta_{1} \alpha_{1}$ ) wat deurgaans in 1 Johannes gebruik word, dui aan dat hier sprake is van 'n gebeurtenis wat permanent in die lewe van 'n gelowige betekenis het. Hierdie permanente betekenis van die

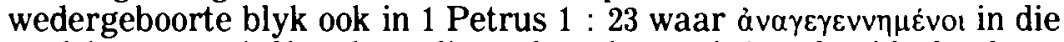
perfektum passief beteken: die wedergeboorte is ' $n$ voltooide daad van God wat in die hede steeds voortgaan (perfektum) en dit is God wat aktief werk (Goddelik passief/Passivum Divinum). Volgens 1 Petrus $1: 3$ word God as die aktiewe in die wedergeboorte aangedui : ávarevvñac is 'n aoristus-aktief: God het ons wederbaar, "has begotten us again" (New King James Version, 1982).

Net soos iemand wat gedoop is nie daardie band met God mag ignoreer nie, so kan iemand nie die wedergeboorte ignoreer nie. Dit is 'n geboorte wat God laat plaasvind. En die werk van die Heilige Gees (vergelyk paragraaf 3) is die wyse waarop God sy werk in die wedergeboorte voortsit.

Die klem wat die Skrif plaas op die feit dat God die wedergeboorte bewerk, beteken nie sonder meer dat die mens dus totaal passief in sy eie wedergeboorte is nie. Die indruk mag bestaan dat die mens in sy eie doop aktief betrokke is, maar nie in sy wedergeboorte nie. Soos later sal blyk (paragraaf 5), geskied die wedergeboorte deur die Woord (1 Pet $1: 23$ ), wat dus beslis van die mens ook ' $n$ bepaalde aksie vereis. Ook die dopeling word gestel voor die eise van die Woord (Matt $28: 19$, Hand $8: 35$ - 37). In hierdie opsig is daar ook 'n ooreenkoms tussen doop en wedergeboorte.

\section{Gevolgtrekking}

Die Skrif se gegewens beklemtoon sonder meer dat God sentraal is in die doop en die wedergeboorte van die gelowiges.

Tussen doop en wedergeboorte kan onderskei word daarin dat God se opdrag in die doop deur 'n mens uitgevoer word en dat God se daad in die wedergeboorte deur Hom self tot uitvoering gebring word. Die doop is veral God se teken aan die mens, die wedergeboorte is veral God se werk in die mens.

\section{CHRISTUS IS SENTRAAL}

In Romeine $6: 3,4$ word daarop gewys dat die doop die gelowiges so met Christus verbind ". . . dat hetgeen eenmaal met Christus is geschied ook op hen van toepassing is" (Ridderbos, 1959:126). Die doop verbind ' $n$ 
gelowige met die dood en die lewe van Christus (vergelyk Ef $2: 5$; Kol $2: 12$ ). Op hierdie wyse kry die gelowige deel aan die versoening deur Christus se sterwe en aan die lewenskrag deur Christus se opstanding. Daar is in die gelowige nou die krag tot 'n sedelike lewensvernuwing.

Die Nuwe Testament sien die band aan Christus nie as net 'n krag tot 'n nuwe sedelike lewe nie, maar as 'n geheel nuwe bestaan. In 2 Korintiers 5 : 17 word gesê: "Iemand wat in Christus is, is 'n nuwe skepsel."

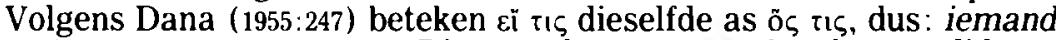

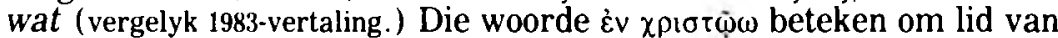
Christus se liggaam te wees en daarom geheel deur Hom geregeer te word (vergelyk Grosheide, 1959: 167.) Hierdie heerskappy van Christus, ook oor die gelowige, word deur Christus self in Matteus 28 : 18 aangekondig: "Aan My is alle mag gegee in die hemel en op die aarde." (1983-vertaling.) In $28: 20$ beloof $\mathrm{Hy}:$ " $\mathrm{Ek}$ is by julle al die dae tot die voleinding van die wêreld." (1983-vertaling.) Deur die doop word 'n gelowige dus aan die persoon Jesus Christus verbind (vergelyk Floor, 1983:28). En Hy beloof sy persoonlike bystand en teenwoordigheid in Matteus $28: 19,20$. In die doop is daar dus sprake van iets intiem-persoonlik wat tussen Christus en die gelowige tot stand kom. Hierdie persoonlike band is klaarblyklik nie net eie aan die wedergeboorte nie.

Dit is hierdie band aan Christus wat so belangrik is. Die doop bring egter nie hierdie verbinding tussen Christus en die gelowige op eie krag tot stand nie, maar is die middel waardeur God handel (Ridderbos, 1971:293).

Van die wedergeboorte word genoem dat die gelowige aan die opstanding van Christus verbind word (1 Pet $1: 3 ; 3: 21$ ). Die wedergeboorte is God se daad aan 'n mens deur die opstanding van Jesus Christus: ". . . the resurrection of Jesus Christ, i.e., His penetration to a new state of being, enables us to speak of regeneration ..." (Buchsel, 1969:674.) Jesus se opstanding het dus die weg gebaan vir die gelowige om ook tot 'n nuwe staat van lewe deur te dring. Volgens 1 Petrus $1: 3-5$ word die hoop ( $\varepsilon i \zeta \xi \lambda \pi i \delta \alpha)$ vir die gelowige gegee sodat hy deur $(\delta i \dot{\alpha})$ die opstanding van Jesus kan vooruitsien na die erfenis wat vir hom bewaar word. Die opstanding van Christus gee aan die wedergeboorte 'n eskatologiese betekenis. Dit gaan nie maar om krag te hê net vir hierdie lewe nie, alhoewel die beproewinge van hierdie lewe en die hantering daarvan 'n belangrike tema in 1 Petrus is (vergelyk Kendall, 1986:115).

Hoewel die wedergeboorte nie in soveel woorde aan die sterwe van Jesus verbind word nie, is dit tog duidelik uit byvoorbeeld 1 Petrus $1: 3$ dat die ontferming van God die basis vir die wedergeboorte is. God se ontferming is geopenbaar in die koms en werk van Jesus Christus (vergelyk Joh $3: 16$ ). Die wedergeboorte kan nie van Jesus se sterwe losgemaak word nie.

\section{Gevolgtrekking}

Die doop en die wedergeboorte beklemtoon beide die besondere band tussen Jesus Christus en die gelowige. Die totale werk van Jesus is die basis vir doop en wedergeboorte. Beide dra 'n persoonlike klem wat die gelowige onder die heerskappy van Christus plaas. Beide verbind die 
gelowige aan die verlede, die hede en die toekoms wat deur Christus vir sy kinders bewerk is en bewerk word.

\section{DIE HEILIGE GEES IS SENTRAAL}

Petrus se woorde op Pinksterdag in Handelinge 2 : 39 beklemtoon die nou band tussen die doop en die werk van die Heilige Gees: "Bekeer julle en laat elkeen van julle gedoop word . . . (dan) sal julle die Heilige Gees as gawe ontvang." (1983-vertaling.) Die futurum sal ontvang skep die ruimte tussen doop en die ontvangs van die Heilige Gees. "Soos die Christelike doop op die vergewing van sondes gerig is, so is die doop ook op die gawe van die Gees gerig." (Floor, 1983:36.)

Hierdie eenheid tussen die doop en die werk van die Heilige Gees word duidelik deur Christus aangedui in Johannes $3: 3$ - 8 .

Die klem val eers op vers 5. Die feit dat daar nie 'n lidwoord voor $\pi v \varepsilon u$ -

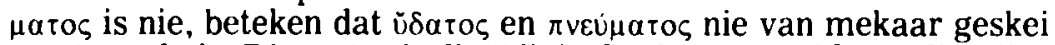
moet word nie. Die water is die "divinely chosen earthly medium" en die Gees is die "regenerating agent who uses that medium" (Lenski. 1943: 237). Dit beteken egter nie dat water en Gees presies identies is nie (soos deur Van der Waal beweer, vergelyk Van der Waal, 1984:39). Die betekenis van vers 5 is dat die Gees in die water werkende besig is.

Maar kan water en doop in Johannes $3: 5$ sonder meer met mekaar geidentifiseer word? Doop word nie hier as tegniese term gebruik nie (soos ook nie in Tit 3:5 nie.) Om uit water gebore te word, het in die tyd van Johannes die Doper se doop in die Jordaan, 'n bepaalde betekenis gehad (hoewel Jesus nie hier van die doop van Johannes praat nie). Die gedagte van Jesus dat iemand uit water gebore moet word, stem ooreen met die nuwe begin wat aangebreek het vir elkeen wat deur Johannes gedoop is. Hiermee saam is die reinigende werking van die water ook van belang. In die doop is sprake van die reiniging (vergewing) van sondes (vergelyk Hand $2: 38$ ), so ook is die water teken van hierdie reiniging (vergelyk Lenski, 1943:237-8; Grosheide, 1950:212).

Johannes $3: 5$ handel dus oor hierdie reinigende werk van God, wat in die Christelike doop bely word as die vergewing van die sondes.

Kan die werk van die Heilige Gees hier sonder meer met wedergeboorte geidentifiseer word? In hierdie verband moet $1: 13$ in ag geneem word (vergelyk Dodd, 1953:305: "it is by 'receiving the Logos' that man gains the right to be God's child"). Daarvolgens is elkeen wat vir Jesus aangeneem het en in Hom glo $(1: 12)$ uit God gebore $(1: 13)$. Hier is dus sprake van 'n geboorte van God af. Hierdie selfde gedagte word aangesny deur ăv() $\theta \varepsilon v$ in $3: 3$ (wat beteken van bo af en van nuuts af). En hierby sluit $3: 5$ aan: 'n geboorte uit die Gees is ook so 'n geboorte van bo af. Hierdie waarheid word bevestig deur 3 : 6 waar die geboorte uit vlees en uit Gees teenoor mekaar gestel word.

Die gevolgtrekking is dat Johannes $3: 5$ inderdaad oor die doop en die wedergeboorte handel. Die reinigende werk van Jesus Christus (water) en die wederbarende werk van die Heilige Gees (Gees) word hier aan 
mekaar verbind. In die werk van die Heilige Gees is daar dus 'n besondere eenheid tussen doop en wedergeboorte.

In Titus $3: 5$ is die uitgangspunt dat die mens se eie werke hom nie kan

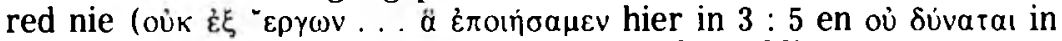
Johannes $3: 3,5$ ). Die enigste oplossing vir die redding (" $\tau \varepsilon \sigma \omega \sigma v)$ van

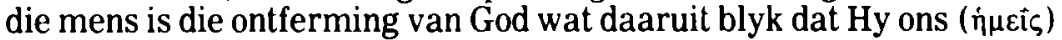
red deur die bad van die wedergeboorte, naamlik die vernuwing deur die Heilige Gees. Ons neem kai dus epeksegeties en beskou vernuwing van die Gees as 'n verduideliking by bad van die wedergeboorte (vergelyk ook Ridderbos, 1971:248). Die vernuwing deur die Heilige Gees staan immers nie los van die wedergeboorte nie, maar begin juis daar. Ook Bouma (1942:441) sien vernuwing hier nie as "doorgaande levensvernieuwing" nie, "maar de vernieuwing naar haar karakter, principieel aangevangen in de wedergeboorte, zoals in de knop het gehele nieuwe leven van de blom reeds verborgen ligt." Donelson (1986:138) dui aan dat volgens Titus $3: 5$ “ . . God as saviour manages salvation through the cultic act of baptism which produces an anthropological transformation through the gift of the spirit".

In paragraaf 2 hierbo is reeds daaroor gehandel dat die bad van die wedergeboorte op die doop betrekking het. Hieruit volg dat die Heilige Gees volgens Titus $3: 5$ by beide die doop en die wedergeboorte betrokke is.

In 1 Johannes is enkele kere sprake dat die gelowige uit God gebore is $(2: 29 ; 3: 9 ; 4: 7 ; 5: 1,4,18)$. In $3: 9$ is daar 'n moontlike direkte verwysing na die Heilige Gees in die woord o $\pi \dot{\varepsilon} \mu \alpha$ (saad): "Elkeen wat uit God gebore is, doen geen sonde nie, omdat sy saad in hom bly." (1983vertaling: “. . . omdat die Gees van God in hom bly".) In hierdie vers gaan dit om die dade van God wat in die lewe van die gelowige hom van die sonde weerhou, want die gelowige is uit God gebore. Die woord saad kan dus noukiks op iets of iemand anders dui as op 'n daad van God. Dus is die voor-die-hand-liggende dat dit hier handel oor die Heilige Gees (vergelyk Schnackenburg, 1984:190). Die woord $\mu \varepsilon \dot{v \varepsilon}$ in die praesens wys op dievoortgaande teenwoordigheid van die Heilige Gees in die gelowige. Hy bly in die gelowige vanaf die wedergeboorte.

In die lig van hierdie verklaring van 1 Johannes $3: 9$ is dit geregverdig om dieselfde interpretasie ook aan die ander genoemde Skrifgedeeltes uit 1 Johannes te heg, naamlik dat uit God gebore die werk van die Heilige Gees met die wedergeboorte aandui. Die perfektum $\gamma \varepsilon \gamma \varepsilon \dot{\varepsilon v \eta} \tau a I$ bevestig wat hierbo gesê is dat die Heilige Gees se werking met die wedergeboorte begin en daarna voortduur.

\section{Gevolgtrekking}

Uit bogenoemde gegewens is dit duidelik hoe betrokke die Heilige Gees in die doop en die wedergeboorte is. Hierdie werk is so ingrypend vir die gelowige omdat die doop ' $n$ bevestiging gee dat die Heilige Gees by die doop betrokke is en die wedergeboorte die teenwoordigheid van die Heilige Gees in hom verseker. 
Die drie-enige God is op verskillende wyses by die gelowige se doop en wedergeboorte betrokke. Dit is nou belangrik om ondersoek te doen na die volle implikasies hiervan vir die bestaan en vir die lewenswandel van die gelowige.

\section{OPENBARINGSHISTORIES EN HEILSORDELIK}

Onder hierdie twee begrippe verstaan ons dat die nuwe heilstyd met die koms en die werk van Jesus aangebreek het en openbaringshistories die bestaan van die sondige wêreld ten goede bepaal. Hierdie heilstyd sluit ook die koms en die werk van die Heilige Gees in. Aan hierdie heerskappy van Jesus Christus kry die gelowige heilsordelik deel deur daarin te glo en daarvolgens te leef.

Wanneer Jesus in Johannes 3 vir Nikodemus verduidelik dat niemand die koninkryk van God kan sien (vers 3 ) of in die koninkryk kan ingaan (vers 5) as hy nie weer gebore word nie, beteken dit dat die openbaringshistoriese werklikheid van God se koninkryk reeds in Jesus se koms aangebreek het. In die tekens wat Jesus gedoen het (Joh $2: 23$ ), het Nikodemus hierdie werklikheid waargeneem, maar nog nie gesien nie. Die tekens het by hom die vraag laat ontstaan of Jesus wel "van God af gekom het" ( $3: 2)$. Maar, sê Jesus, dit is nie genoeg nie. Wat nog moet gebeur, is dat Nikodemus (in hierdie geval enigiemand) heilsordelik weer gebore moet word $(3: 3,5)$. Eers dan kan hy die koninkryk sien, dit beteken: ingaan in die koninkryk (vers 5 ) en deel wees van Christus se volle heerskappy. Die wedergeboorte is, volgens Jesus in $3: 5$, die wyse waarop hierdie heilsordelike gebeure in die lewe van die gelowige plaasvind.

Dit is dan belangrik om in gedagte te hou dat water in Johannes $3: 5$ op die doop betrekking het (vergelyk paragraaf 3 ). Die doop maak dus ook duidelik dat die gelowige heilsordelik deel het aan God se heerskappy. In die doop is daar wel ' $n$ duidelike aankondiging van die openbaringshistoriese werk van die drie-enige God, omdat in sy Naam gedoop word. Maar die wedergeboorte is in wese gebaseer op dieselfde werk van die drie-enige God. Doop en wedergeboorte handel beide oor hierdie band aan God.

Titus $3: 5$ beskryf ook wat in die individuele gelowige gebeur met die wedergeboorte (heilsordelik) met verwysing na die vernuwing deur die Heilige Gees. Hierdie vernuwing van die Heilige Gees het openbaringshistories met Pinkster aangebreek. Beasley-Murray (1979:278) noem die wedergeboorte die counterpart van dit wat met Pinkster vir die kerk aangebreek het. Wanneer 'n persoon gedoop word in die Naam van die Heilige Gees, kry hy ook deel aan hierdie seëninge wat met Pinkster vir die kerk aangebreek het. Maar steeds moet hy hierdie seeninge met 'n ware geloof omhels, en dit doen hy deur die wedergeboorte wat in hom gewerk word deur die Heilige Gees.

Steeds is wedergeboorte en doop inhoudelik dieselfde, hoewel dit twee verskillende gebeure in die lewe van die gelowige is.

Die voortdurende betekenis van die volle Evangelie word ook in die doop 
en wedergeboorte gevind. Die doop kry sy permanente betekenis vir die gelowige uit die feit dat die gedoopte met water, ook met die Gees gedoop is (Joh $3: 5$ ), wedergebore is. Hierdie geboorte uit God (1 Joh $2: 29$; $3: 9$ ter aangehaalde plaatse) word, soos reeds aangedui, telkens in die perfektum aangedui. Die Heilige Gees is van die wedergeboorete af voortdurend by die gelowige.

Volgens 1 Petrus $1: 3$ - 5 is die wedergeboorte geskenk tot 'n lewende hoop. Hierdie hoop is gerig op 'n erfenis wat onverganklik, onbesmet, onverwelklik is. Met hierdie woorde word die absolute sekerheid van die gelowige geformuleer. Dit is 'n sekerheid wat in die wedergeboorte ingebed is. Hierdie sekerheid strek hom eskatologies uit tot die laaste tyd ( $\dot{\varepsilon} v \kappa \alpha \iota p \hat{\varepsilon} \sigma \alpha \alpha \dot{\alpha} \omega$ - vers 5). Dit is 'n sekerheid wat nie vanselfsprekend die deel is van almal wat gedoop is nie, maar iemand wat wedergebore is kan glo dat hy hierdie erfenis sal ontvang.

\section{Gevolgtrekking}

Die feit dat iemand wedergebore is, gee 'n sekerheid wat eskatologies tot die laaste tyd toe strek. Die wedergeboorte gee aan die gelowige die volle sekerheid dat hy heilsordelik deel het aan die openbaringshistoriese heerskappy van Jesus Christus. Dit wat in die doop aan hom gegee is, word sy eie deur die wedergeboorte.

\section{5. 'N NUWE BEGIN}

Hier word nagegaan wat die praktiese gevolge van die doop en wedergeboorte vir die individuele gelowige is.

In die eerste plek is daar by die gelowige die sekerheid van sy eie saligheid en redding.

Volgens Titus $3: 5$ het God ons gered deur die bad van die wedergeboorte en die vernuwing deur die Heilige Gees. Dit is nie korrek as Bouma (1942 441) beweer dat $\delta$ ıa net op bad betrekking het nie. Eerder word die doop en die wedergeboorte, en daarmee saam ook die vernuwing deur die Heilige Gees, deur $\delta i \alpha$ bepaal (vergelyk Floor, 1983:61,61). Dit is die wyse waarop God die gelowiges red, uiteraard op grond van sy ontferming ( 1 Pet 1:3). Die volle Evangelie word in sy doop aan die gelowige geskenk en deur die wedergeboorte kry hy die sekerheid dat hy waarlik die saligheid in Christus ontvang het.

Die wedergeboorte is die geboorte-oomblik wanneer die gelowige hierdie sekerheid in sy eie gemoed ervaar. Die woord to(uoev in Titus $3: 5$ is ' $n$ ingressiewe aoristus wat die doop en die wedergeboorte as die begin van die verlossing beskryf.

Die betekenis van die woord $\pi \alpha \lambda ı \gamma \gamma \varepsilon v \varepsilon \sigma i a$ (wedergeboorte) moet nie vanuit sy gebruik in buite-Bybelse verband (vergelyk hiervoor onder andere Lock. 1936:154) verklaar word nie. Dit is beter om hierdie woord uit die verband in Titus 3 te verklaar. Wedergeboorte het in Titus $3: 5$ op die individuele gelowige se lewe betrekking, en hier word as 'n nadere verklaring bygevoeg: die vernuwing deur die Heilige Gees Die begrippe wedergeboorte en vernuwing moet, volgens Ridderbos (1967 293) ver- 
staan word teen die agtergrond van wat in die Nuwe Testament met nuut bedoel word, naamlik in heilshistoriese, eskatologiese sin. "De bedoeling van het hier gebruikte begrip is om aan te duiden, dat het met Christus aan het licht getreden nieuwe leven (vergelyk 2 Tim $1: 8$ ), dat een principieel eschatologisch karakter draagt, zich reeds in dit leven aan die gelovigen meedeelt" (1967:294).

Die gelowige moet, kragtens sy wedergeboorte, sy eie lewe in 'n totale nuwe lig sien. Hy moet tot die besef kom dat hy nie meer aan die sondige wêreld vasgekluister is nie, maar dat hy in Christus van die mag van die sonde verlos is. Dit moet hom daartoe lei om as 'n oorwinnaar oor die sondes te leef.

Uit hierdie gegewens blyk dat die doop en die wedergeboorte beide hierdie ingrypende feit van sy volledige verlossing en vernuwing van sy lewe in die gelowige se lewe duidelik maak en deel van sy lewe laat wees. In die tweede plek lei hierdie verlossing van die sondes die gelowige tot 'n breuk met die sonde.

Die gelowige is met sy doop geestelik in die dood van Jesus Christus ingedompel (Rom $6: 3-11$ ). Dit beteken nie net dat hy van sy sondes verlos is nie, maar dat die ou mens, wat aan die sonde en dus aan die dood onderworpe is, self deur die dood van Christus vernietig word. Die gelowige worstel steeds met sy sondige natuur en hy verafsku dit omdat hy in die Naam van die drie-enige God gedoop is (Anon, 1876:46).

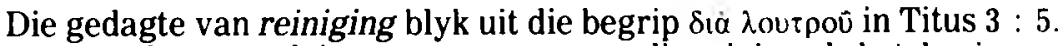

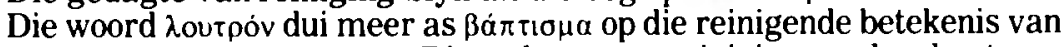
die doop (Ridderbos, 1967:293.) Die gedagte van reiniging word onderstreep deur die teenstelling wat dit vorm met die onreinheid van die ongelowige in $1: 15$ en $2: 14$. "We needed cleansing ... with a washing that would entirely renew our nature." (Lock, 1936:154.) Die doop "illustreer vir ons die reiniging wat noodsaaklik is om deel te kan hê aan die nuwe lewe wat Christus verwerf het" (Floor, 1983:63). Die woorde van Jesus aan Nikodemus in Johannes $3: 5$ het ook hierdie reinigende betekenis van die water op die oog gehad: Iemand kan eers in die koninkryk van God ingaan as hy hierdie reiniging ondergaan het.

Hierdie reiniging raak die gelowige se eie lewe so ingrypend dat 1 Johannes 3 : 9 kan sé: "Elkeen wat uit God gebore is, doen nie sonde nie." (Vergelyk ook $2: 29 ; 5: 4,18$.) Iemand wat uit God gebore is, is nie onder die heerskappy van die duiwel nie. Die wedergeboorte gee aan die gelowige die krag om te leef volgens die evangelie wat met sy doop aan hom beseel is.

Die voortgaande veral. .ering wat in die gelowige plaasvind wanneer hy hoe langer hoe meer die sonde afsterf, word in Romeine $12: 2$ en

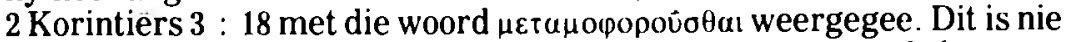

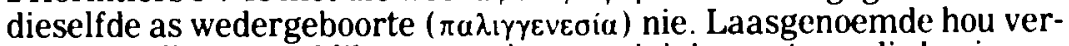
band met die aanvanklike vernuwing en reiniging wat aan die begin van die gelowige se geloofslewe plaasvind. 
In 1 Petrus 1 word geloof ( $\delta ı \dot{\alpha} \pi i \sigma \tau \varepsilon(s \zeta$ - vers 5), hoop ( $\varepsilon i \zeta \dot{\varepsilon} \lambda \pi i \delta \alpha$ - vers 3 ) en liefde ( $\dot{\alpha} \gamma a \pi \eta \dot{\sigma} \sigma \tau$ - vers 22 ) genoem as die kenmerke van die wedergeborene $(1: 3,5,23)$ se lewe (vergelyk geloof, hoop en liefde in 1 Kor $13: 13$ ). Volgens $1: 3$ is 'n wesenlike bedoeling waarom God die wedergeboorte aan die gelowige gee, dat hy 'n lewende hoop sal hê. 'n Verdere vrug van die wedergeboorte is dat die gelowige seker is van die erfenis wat hy gaan verkry. En hierdie sekerheid het hy deur die geloof (vers 5). Volgens $1: 23$ is die feit dat die gelowige wedergebore is, die rede dat die gelowiges onderlinge liefde (vers 22) moet betoon. So word die hele Christelike lewe deur die wedergeboorte geraak.

Gevolgtrekking

Uit bostaande gegewens blyk dat die doop en wedergeboorte 'n alomvattende lewensverandering (sekerheid van saligheid en redding) en lewensvernuwing (breuk met die sonde) in die gelowige se lewe tot gevolg het. Die doop en wedergeboorte is die beginpunt, maar ook die waarborg. vir die voortgang van 'n ware Christelike lewenswandel. Hierdie feite plaas 'n geweldige verantwoordelikheid op die gelowige om volgens sy doop en wedergeboorte te leef.

\section{UITERLIK EN INNERLIK}

Tot dusver het geblyk dat 'n besondere klem in die doop, soos uiteraard ook in die wedergeboorte, val op die innerlike verandering wat in die gelowige plaasvind. Is hierdie innerlike betekenis iets nuuts in die Nuwe Testament? Waarom lyk dit uit Johannes 3 : 10 of Jesus meen Nikodemus behoort, as leraar van Israel, reeds van so 'n geboorte uit water en Gees $(3: 5)$ te geweet het? Het die besnydenis ook so 'n persoonlike, innerlike betekenis gehad?

Uit Romeine $4: 12,13$ blyk dat die besnedene verplig was om in die band tussen hom en God te glo. In wese was die besnydenis nie 'n teken dat die persoon aan Israel behoort het nie, maar dat hy in 'n verbondsverhouding tot God staan (Motyer. 1968:233).

Die feit dat Deuteronomium 30:6 praat van: "Die Here jou God sal jou hart besny en die hart van jou nageslag, om die Here jou God lief te hê ... " (1953-vertaling), dui op die nou band tussen die uiterlike besnydenis en die persoonlike betrokkenheid van die gelowige by hierdie band van God aan hom. Dit is ook die inhoud van Romeine 2:29: "... dit is besnedenheid wat in die hart gedoen is deur die Gees, nie

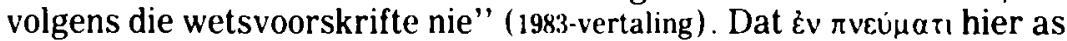
Heilige Gees verstaan moet word, is verkieslik, omdat die teenstelling

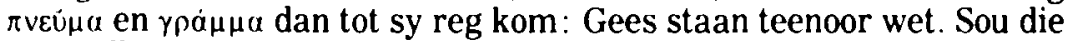
teenstelling gewees het tussen vlees en gees, dan kan $\pi v \varepsilon u \mu \alpha$ op die menslike gees betrekking gehad het. Om in die hart besny te wees, stem dus saaklik ooreen met die wedergeboorte. En dit gee ware inhoud aan die uitwendige seremonie (besnydenis of doop).

Dit moet ook ten opsigte van die doop onderstreep word dat hier nie sprake kan wees dat die uiterlike seremonie self die vernuwing in die gelowige bewerk nie. Die doop is wel 'n teken en 'n seel “. . . to confirm 
our faith in the validity of the covenant to which it is attached" (Hodge, $1975: 67$ ). Maar die doop is nie 'n opus operatum wat self die genade aan die persoon meedeel nie. Hierdie genade word deel van die gelowige se lewe deur die wedergeboorte wat deur die Heilige Gees in hom gewerk word.

Die belangrikste feit in die gelowige se lewe is dus nie op watter tydstip van sy lewe hy gedoop is nie - maar wel dat hy gedoop moet wees en dat hy wedergebore is. Indien die klem oormatig val op die tydstip van die doop, word weer ' $n$ uiterlike betekenis aan die seremonie gegee wat vreemd is aan die Nuwe Testament. Wat wel belangrik is, is dat dit eie is aan ' $n$ gedoopte om wedergebore te wees en dat dit eie is aan 'n wedergeborene om gedoop te wees.

Dit sal ook moeilik wees om uit die Nuwe Testament finale uitsluitsel te kry oor die vraag of ' $n$ mens eers wedergebore en dan gedoop of eers gedoop en dan wedergebore moet wees. Hierdie saak word nie eksplisiet in die Nuwe Testament behandel nie. Daarom behoort eerder by die kern van die saak gebly te word, naamlik dat dit vir elke gelowige belangrik is om uiterlik gedoop te wees as teken van sy band aan God, en innerlik oortuig te wees dat die wedergeboorte in sy lewe plaasgevind het.

Die feit dat die wedergeboorte as 'n daad van God bestempel word (vergelyk paragraaf 1), plaas die klem in die wedergeboorte op die daad van God en nie op die belewing daarvan deur die mens nie. Die waarborg vir die wedergeboorte lè nie in die emosionele binne die mens nie. Dit neem nie weg nie dat die wedergeboorte tog innerlik is en die hart van die mens (Rom $2: 29$ ) raak. So ook, al is die doop 'n uiterlike seremonie en lê die krag daarvan nie in die emosionele belewing daarvan nie, mag nie beweer word dat die doop die hart van die gelowige koud laat nie.

\section{Gevolgtrekking}

Wanneer 'n gelowige oor sy eie doop en wedergeboorte dink, moet hy in ag neem dat die werklike krag van hierdie twee gebeurtenisse in sy lewe daarin bestaan dat dit van buite homself af, dit is van God af, aan hom gegee word en in hom bewerk word. In hierdie sin het doop en wedergeboorte ' $n$ uiterlike betekenis. Vir die gelowige is dit belangrik dat hy gedoop en wedergebore is, en nie soseer wanneer en presies hoe dit gebeur het nie.

Die gelowige moet hom daarop toelê om altyd daarvan bewus te wees dat sy lewe innerlik en uiterlik direk en ingrypend deur sy doop en wedergeboorte beinvloed word.

Die gesonde balans tussen hierdie uiterlike en innerlike betekenis van die doop en wedergeboorte is van die grootste belang. Hierdie balans laat die gelowige ten volle deel in die ontferming en liefde van God wat Hy deur die doop en wedergeboorte aan sy kinders skenk. So ontvang die gelowige die krag en leiding van God om uit sy lewe te laat blyk dat hy innerlik en uiterlik deur God vernuwe is.

\section{BIBLIOGRAFIE}

Anon 1876 Wedergeboorte en Doop. Van Dijk: Zwolle. 
Beare, FW. 1970. The first epistle of Peter. The Greek text with introduction and notes. Oxford: Blackwell

Beasley-Murray, GR. 1979. Baptism in the New Testament. Exeter: Paternoster.

Bigg, C. 1910. A critical and exegetical commentary on the epistles of St Peter and St Jude. (The International Critical Commentary.) Edinburgh: Clark.

Bouma, C. 1942. De Brieven van den apostel Paulus aan Timotheus en Titus. (Kommentaar op het Nieuwe Testament.) Amsterdam: Van Bottenburg

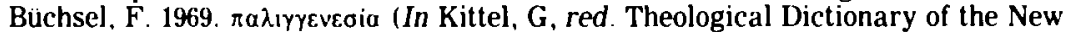
Testament, dl. 1. Grand Rapids: Eerdmans. $p$ 686-9.)

Diermanse, AM. 1907. De uitverkoren kinderen wedergeboren, eisch des Doops? 's Gravenhage: Van Zijl.

Dana, HE \& Mantey. JR. 1955. A manual grammar of the Greek New Testament. Toronto: Macmillan.

Dodd, CH. 1953. The interpretation of the Fourth Gospel. Cambridge: University.

Donelson, LR. 1986. Pseudepigraphy and ethical argument in the Pastoral Epistles. Tubingen: Mohr.

Floor, L. 1979. Hy wat met die Heilige Gees doop. Pretoria: NG Kerk

1983. Die heilige doop in die Nuwe Testament. Potchefstroom : Potchefstroomse Teologiese Publikasies.

Grosheide, FW. 1950. Het Heilig Evangelie volgens Johannes. dl 1. (Kommentaar op het Nieuwe Testament.) Amsterdam: Van Bottenburg.

1957. De eerste brief aan de kerk te Korinthe. (Commentaar op het Nieuwe Testament.) Kampen: Kok.

Hodge, C. 1975. A commentary on Romans. I sondon: Banner of Truth Trust

Kendall. DW. 1986. The literary and theological function of 1 Peter $1: 3$ - 12 (In Talbert, CH, red., Perspectives on First Peter. NABPR Special Studies Series Number 9. Georgia: Mercer.)

Kramer, G. 1897. Het verband van doop en wedergeboorte. Breukelen: De Vecht.

Ienski, RCH. 1936. The interpretation of St Paul's Epistle to the Romans. Minneapolis: Augsburg.

1943. The interpretation of St John's Gospel. Minneapolis: Augsburg

Lock, W. 1936. A critical and exegetical commentary on the Pastoral Epistles. (The International Critical Commentary.) Edinburgh: Clark

Morris, L. 1988. The epistle to the Romans. Grand Rapids: Eerdmans.

Motyer. JA. 1968. Circumcision. (In Douglas, JD, red., The New Bible Dictionary London: Inter-Varsity.)

Ridderbos, H 1959. Aan de Romeinen. (Commentaar op het Nieuwe Testament.) Kampen: Kok.

1967. De Pastorale Brieven. (Commentaar op het Nieuwe Testament.) Kampen: Kok

1971. Paulus, ontwerp van zijn theologie. Kampen: Kok.

Schnackenburg, R. 1984. Die Johannesbriefe. (Herders Theologischer Kommentar zum Neuen Testament.) Freiburg: Herder.

Smelik, EL. 1980. De brieven van Paulus aan Timotheus, Titus en Filemon. (De Prediking van het Nieuwe Testament.) Nijkerk: Callenbach.

Van der Waal, C. 1984. Commentaar op het Evangelie naar Johannes. Goes: Oosterbaan.

Van Bakel, HA. 1913. De oorsprong van den (hristelijken doop Baarn: Hollandia. 